\title{
3D MODELLING THE INVISIBLE USING GROUND PENETRATING RADAR
}

\author{
P. Agrafiotis ${ }^{\mathrm{a}}$, K. Lampropoulos ${ }^{\mathrm{b}}$, A. Georgopoulos ${ }^{\mathrm{a}}$, A. Moropoulou ${ }^{\mathrm{b}}$ \\ ${ }^{a}$ National Technical University of Athens, School of Rural and Surveying Engineering, Lab. of Photogrammetry \\ ${ }^{\mathrm{b}}$ National Technical University of Athens, School of Chemical Engineering, Laboratory of Materials Science and Engineering \\ Zografou Campus, Heroon Polytechniou 9, 15780, Zografou, Athens, Greece \\ (pagraf, klabrop, drag, amoropul)@ central.ntua.gr
}

\section{Commission II}

KEY WORDS: Ground penetrating radar (GPR), 3D modelling, Holy Aedicule

\begin{abstract}
:
An interdisciplinary team from the National Technical University of Athens is performing the restoration of the Holy Aedicule, which covers the Tomb of Christ within the Church of the Holy Sepulchre in Jerusalem. The first important task was to geometrically document the monument for the production of the necessary base material on which the structural and material prospection studies would be based. One task of this action was to assess the structural behavior of this edifice in order to support subsequent works. It was imperative that the internal composition of the construction be documented as reliably as possible. To this end several data acquisition techniques were employed, among them ground penetrating radar. Interpretation of these measurements revealed the position of the rock, remnants of the initial cave of the burial of Christ. This paper reports on the methodology employed to construct the 3D model of the rock and introduce it into the 3D model of the whole building, thus enhancing the information about the structure. The conversion of the radargrams to horizontal sections of the rock is explained and the construction of the 3D model and its insertion into the 3D model of the Holy Aedicule is described.
\end{abstract}

\section{INTRODUCTION}

The National Technical University of Athens has undertaken the huge task to coordinate the restoration the Holy Aedicule in the Church of the Holy Sepulchre in harmonious cooperation with the religious communities responsible for this living monument in Jerusalem. For that purpose, an interdisciplinary team has been formed to study the current situation of the Holy Aedicule and propose the actions necessary for its immediate restoration.

The Holy Aedicule is situated within the large complex of the Church of the Holy Sepulchre in the centre of the Rotunda, a $25 \mathrm{~m}$ tall cylindrical building. The Holy Aedicule is the latest in a series of constructions and additions to the initial Crusader Aedicule which had occupied the same site for centuries (Biddle 1999). Responsible for the design and reconstruction of this latter one was the architect Komninos in the early 19th century. However, in 1927 this construction was badly damaged by an earthquake which also weakened the dome over the Rotunda and other parts of the complex. Marble slabs cover the outside surface of the Aedicule, while it is also surrounded by a metallic construction (Figure 1) erected by the British in 1947 which provides support.

This steel cradle was erected around it from the outside to stop the collapse of the Holy Aedicule. Timber wedges were inserted between the steel girders and the load-bearing stone walls of the Holy Aedicule. It appears that this steel girdle is no longer functional, as lately deformations were observed especially as far as the Komninos' marble slabs are concerned. The inside the Holy Aedicule is a complex structure with two very confined, highly ornamented rooms. The Tomb of Christ is nowadays covered by marble slabs, which embrace the remnants of the initial rock cave of the burial. It was formed like that by the Crusaders during their occupations of the Holy Land in the $11^{\text {th }}$ and $12^{\text {th }}$ centuries. The first task of the interdisciplinary team of NTUA was to perform the geometric documentation of the Holy Aedicule, as foreseen in the Venice Charter (art. 16). This documentation was, of course, part of a wider range of technical studies of an interdisciplinary team of engineering experts. Within this scientific work of studying and analyzing the current situation of the Holy Aedicule a methodology employed to construct the 3D model of the rock and introduce it into the 3D model of the whole building, thus enhancing the information about the structure.

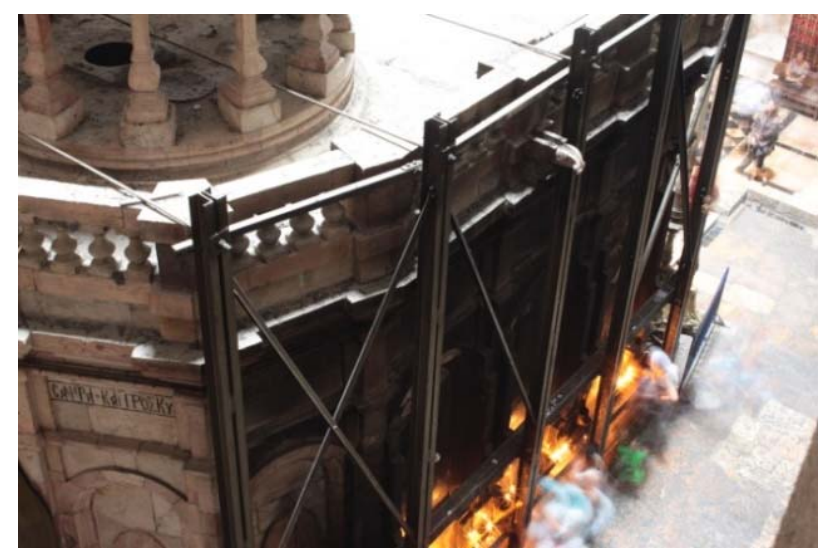

Figure 1: The south façade (2015) of the Holy Aedicule

\section{PREVIOUS WORK}

In the past, several efforts for the geometric documentation of the Church of the Holy Sepulchre and the Holy Aedicule in it took place. Already since the 60's the Franciscan monk Corbo, documented, mainly as an archaeologist, a large part of the Church using of course the then available technological means (Corbo, 1981). Later (Biddle 1992) a team of British experts documented in high detail the Holy Aedicule. In the years 19931999, the Laboratories of General Geodesy and of Photogrammetry of NTUA undertook and executed the complete geometric documentation at a scale of 1:50 of the 
Church of the Holy Sepulchre for the Greek Orthodox Patriarchate (Balodimos et al. 2003, Georgopoulos \& Modatsos 2002, Lavvas 2009). Finally, in the years 2007-2009 a team of Italian experts embarked on terrestrial laser scanning for the complete 3D documentation of the Church (Tucci \& Bonora 2011).

For the current geometric documentation of the Holy Aedicule before the restoration works, several campaigns were necessary. The first one took place in May 2015 (Moropoulou et al. 2015) and the second one in January 2016. Due to the peculiarities of the object of interest and the crowds of pilgrims continuously present inside and around the Aedicule, most of the works for the data acquisition took place at night after the closure of the Church in the evening. The methodology implemented to produce the above described products applied the most contemporary techniques and specialized instrumentation. Briefly, an automated 3D imaging methodology based on high resolution digital images, terrestrial laser scanning and high accuracy geodetic measurements were implemented. These data were georeferenced to an already existing reference system from previous work of NTUA (Balodimos et al. 2003).

For the needs of this documentation it was decided to produce a high resolution three-dimensional textured model and to perform specialized high accurate geodetic measurements for the production of conventional 2D base material on one hand and for the documentation of the deformations and deviations of the construction today on the other.

\section{METHODOLOGY}

\subsection{GPR Measurements}

Within this integrated study data were also collected for the documentation of the exterior and the interior of the structure using non-destructive techniques. Ground Penetrating Radar (GPR) is an established non-destructive technique (Binda et al. 1998, Binda et al. 2000, Moropoulou et al. 2013, Moropoulou \& Labropoulos 2015), which exploits the wave character of electromagnetic fields and is based on the propagation and analysis of electromagnetic radiation to image the examined structure. The ground penetrating radar system used in this survey was a MAL $\AA$ Geoscience ProEx system with $1.6 \mathrm{GHz}$ and $2.3 \mathrm{GHz}$ antennae. The MALA Geoscience Groundvision 2 software was used for data acquisition. The MALÅ Geoscience RadExplorer v.1.41 software was used for data processing. GPR Surveys were conducted along profile lines to produce 2-D sections of the subsurface. The signal obtained from the interior of a surveyed structure is the composite result of primary reflections from distinct interfaces or targets, multiple echoes from secondary reflections and superposition phenomena of the diffusing and reflecting waves.

Horizontal scans (Figure 2) were conducted from height level $70-200 \mathrm{~cm}$ above the exterior ground level for both the southwest and northwest parts of the Aedicule, whereas, for the southwest part, scans at $210-315 \mathrm{~cm}$ height levels were additionally performed. The calculation of the pulse velocities throughout all observed layers is required to convert the time scale of the GPR scans into depth scale. For this purpose, stone blocks of the parapet at the roof and stone blocks from the seat outside the entrance to the Aedicule were scanned to calibrate the pulse velocities for the GPR analysis. The velocities and dielectric constants were calculated and used in the velocities models of the remaining areas, representing the exterior stone panels and the holy rock, as they have similar synthesis. Based on this calibration, a velocity of $v=11,58 \mathrm{~cm} / \mathrm{ns}(\sigma=1,02 \mathrm{~cm} / \mathrm{ns})$ was calculated. A pulse velocity of $10 \mathrm{~cm} / \mathrm{ns}$ was used for the 1810 filler mortar layer based on scans in the S2 area, where the masonry most probably dates to 1810 and is lined with stone/marble panels, both in the exterior and the interior of the structure. For the main masonry, a pulse velocity of $10,48 \mathrm{~cm} / \mathrm{ns}$ was used based on the results from a previous diagnostic study with non-destructive techniques by the NTUA research team for the Bell Tower of the Church of the Holy Sepulchre (Labropoulos \& Moropoulou 2013).

After data processing and application of the velocity models and after reverse and rotation, as required, the scans were overlaid on the Aedicule horizontal plan at the respective positions and orientations. From analysis of the various horizontal and vertical GPR scans, the observed phases inside the structure of the Aedicule were analysed (Figure 3). Specifically, at its western part, from the exterior towards the interior of the burial chamber, the layering is the following:

a) exterior panel

b) Komnenos filler mortar layer (1810)

c) main masonry (either dating to the $11^{\text {th }} / 12^{\text {th }}$ century or reconstructed in 1810 by Komnenos

d) Holy Rock

e) interior masonry between Holy Rock and interior panel, and f) interior panel

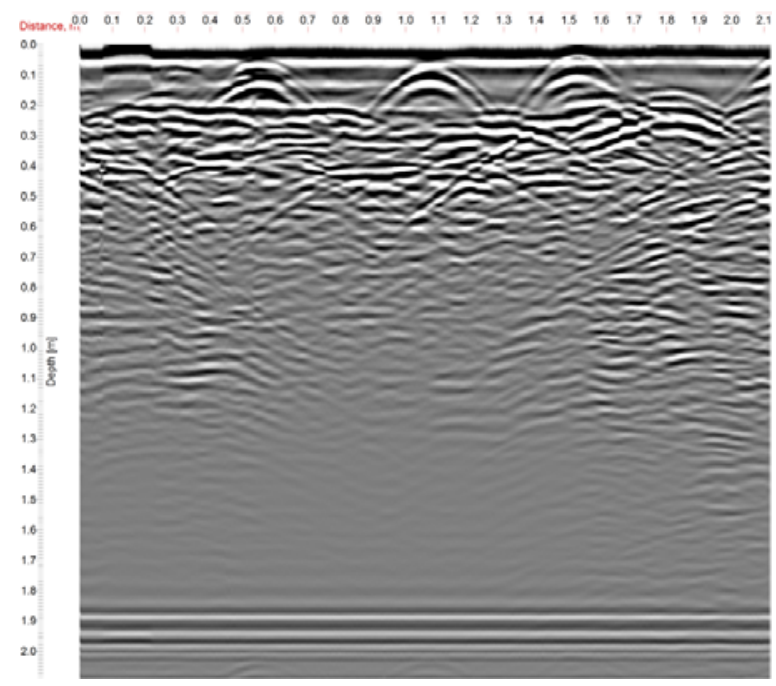

Figure 2: An example of GPR scan used for this application

Based on this 3D model horizontal sections were produced for the outside and inside part of the Holy Aedicule. These sections were given to the members of the interdisciplinary team from the Laboratory of Materials in order to serve as the necessary base material to visualize the prospections and related measurements already performed.

\subsection{Modelling}

The 3D representation of the results of the non-destructive prospection with the GPR for the internal structure of the Holy Aedicule was considered highly useful. The contribution of this $3 \mathrm{D}$ visualization and correlation of the interpreted GPR measurements is very important for this study, as it represents the internal structure of the Holy Aedicule, which is not directly visible. 


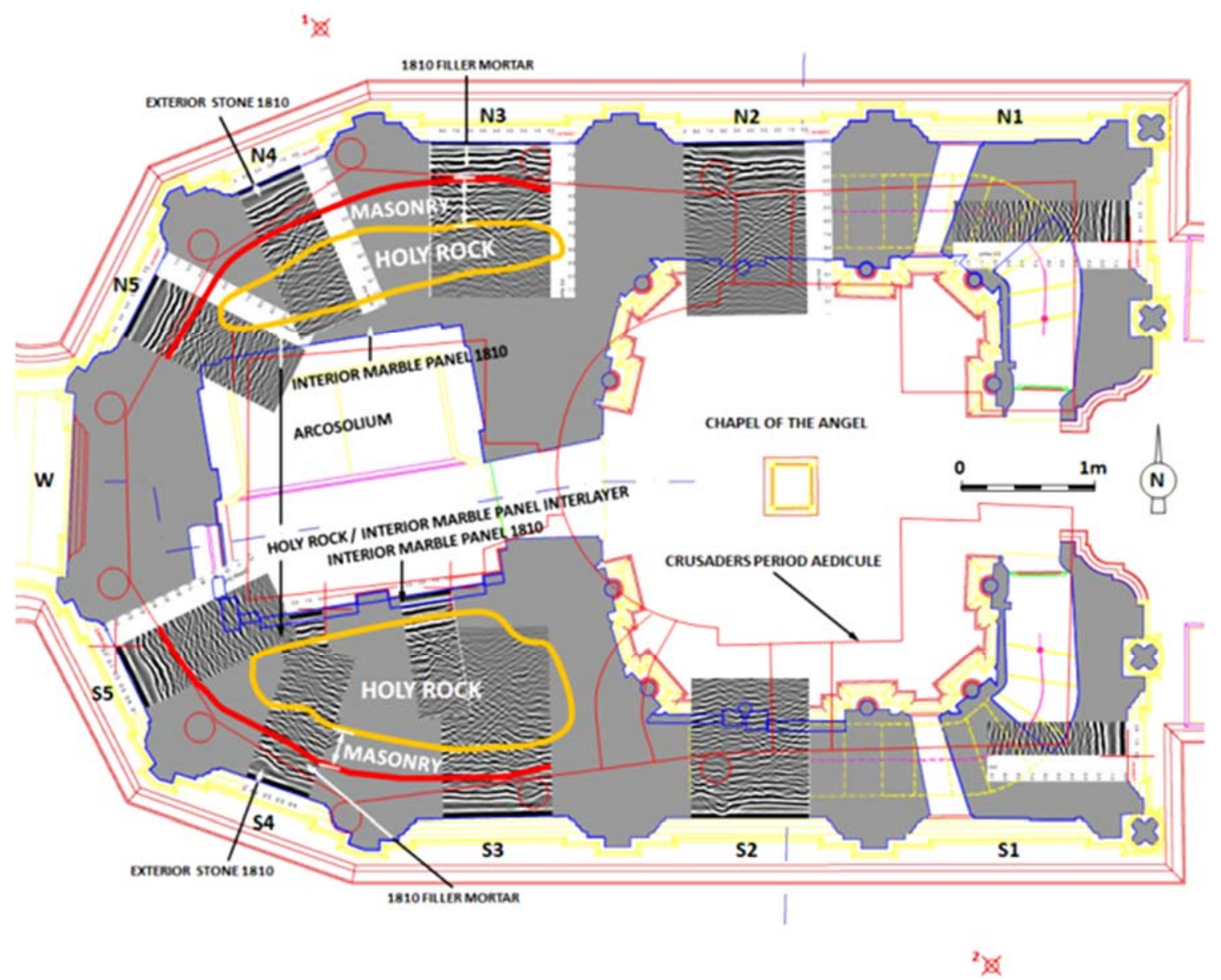

Figure 3: Overlay (layer height $130 \mathrm{~cm}$ ) of data processed GPR scans on the plan of the Holy Aedicule, and identification of the construction layers of the structure. The red outline of the Crusaders' period Aedicule is also indicated in the plan.

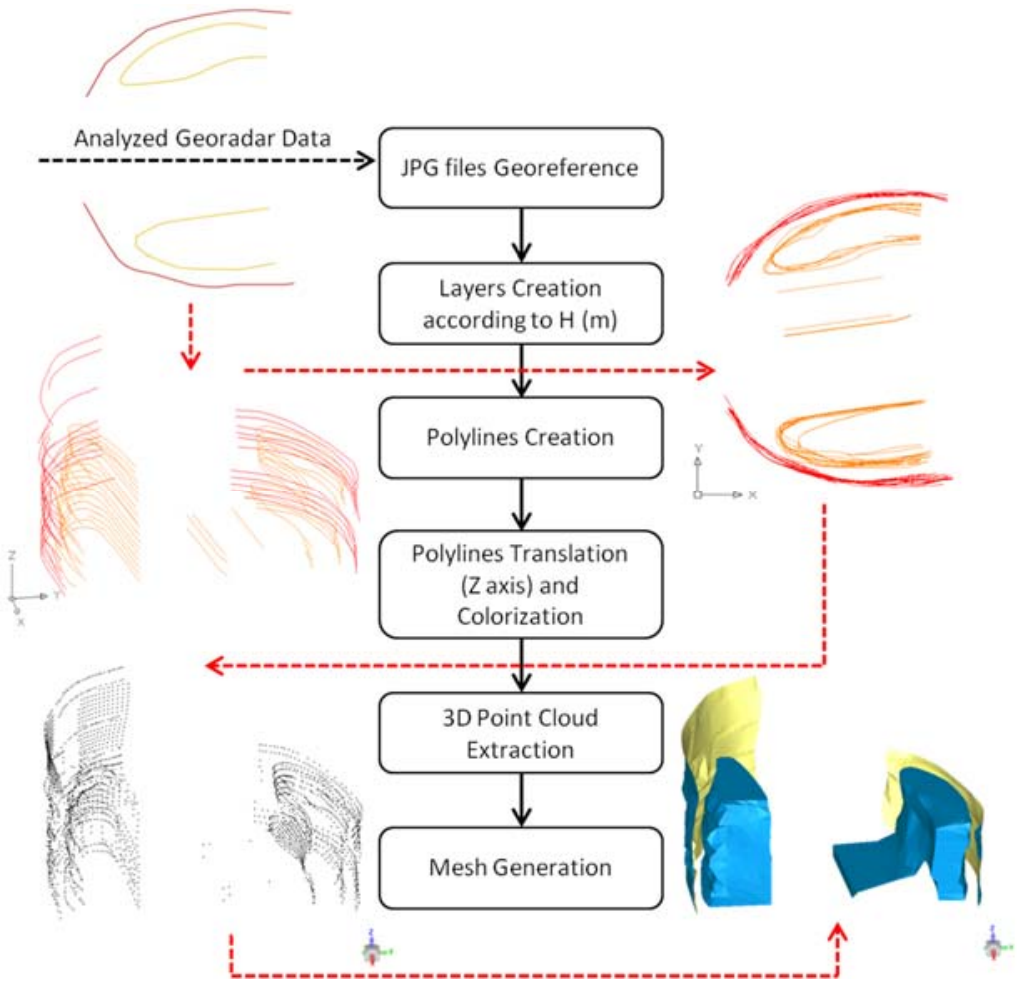

Figure 4: Flowchart of the methodology developed for the creation of the 3D model of the internal structure of the Holy Aedicule 
The main aim is to enable the advanced interpretation of the initial GPR observations from the experts and the feeding of the structural study with this invaluable information. The flowchart of the methodology developed for the creation of the 3D model of the internal structure of the Holy Aedicule is presented in Figure 4. Initially the 23 images of the 2D horizontal sections of the GPR were georeferenced, based on the same two distinct points, to the common reference system already established and described. More specifically, the sections used described the internal structure of the Holy Aedicule from a height of $0.2 \mathrm{~m}$ upwards with a step of $+0.10 \mathrm{~m}$ up to $2.00 \mathrm{~m}$. Some sections were also performed above that height at $2.15 \mathrm{~m}, 2.70 \mathrm{~m}$ and $2.90 \mathrm{~m}$. The lines of the sections appearing on the images were converted into vector files and the resulting polylines were suitably coloured: Red colour was chosen for the outside border line of the 12th century masonry and orange for the external and internal border line of the rock (Figure 5).
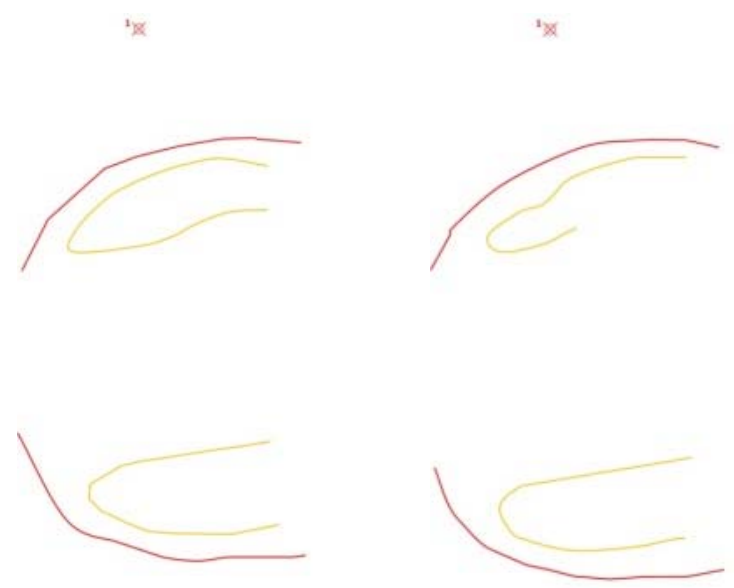

Figure 5: Analysis results of the GPR data (2D sections) for heights $0.30 \mathrm{~m}, 0.70 \mathrm{~m}$ and $1.20 \mathrm{~m}$

In Figure 6 the boundary lines of the various materials detected are presented as 2D sections of the internal structure, as it was determined by the above presented analysis. Subsequently they were placed in different layers in the CAD environment according to their height attribute. They would contain the digitized border lines, alternatively 2D sections as polylines thus resembling contour lines.

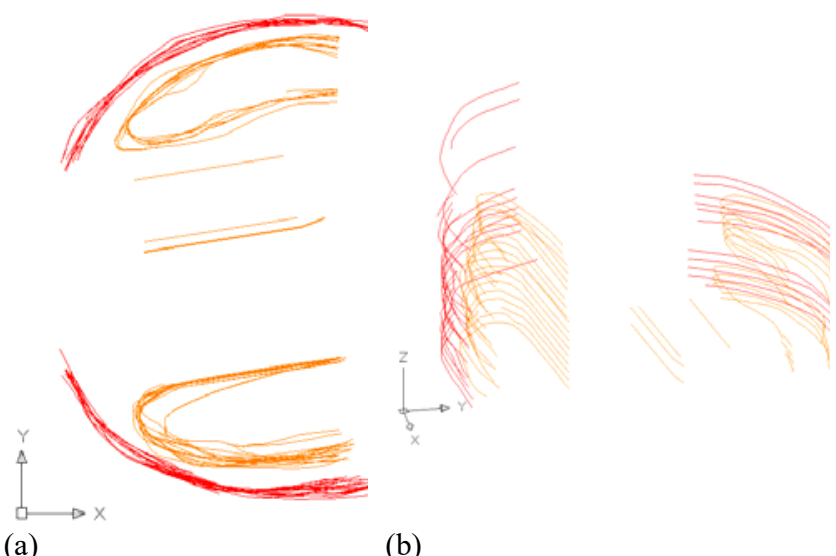

(a)

(b)

Figure 6: All the digitized 2D sections in plan (a) and in 3D presentation (b) after the assignment of the correct elevation.
Afterwards, each of these lines was transferred to its real height in the common reference system. In this way, the 2D information was converted to 3D (Figures 5, 6 and 7). The coordinates of the nodes were then extracted from the drawn polylines in a .txt file. This file was imported into a point cloud and surface processing software (Figure 8), where the desired surface was created and was subjected to the final processing for its integration and completion with the help of careful interpolation (Figure 9).

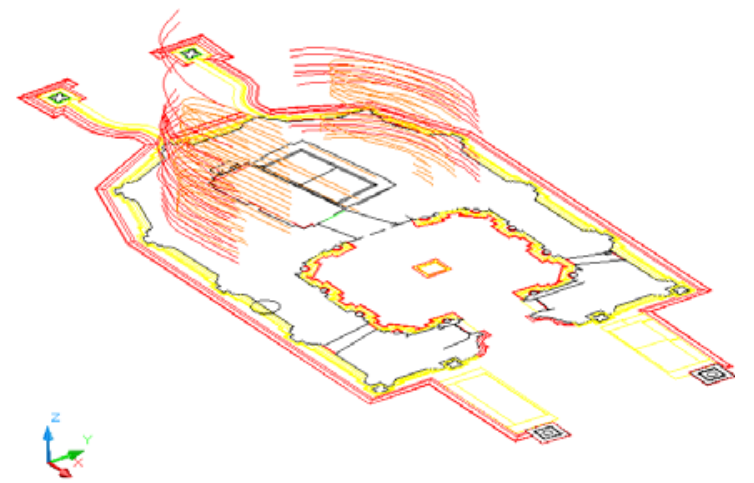

Figure 7: All the polylines referenced to a horizontal section of the Holy Aedicule.

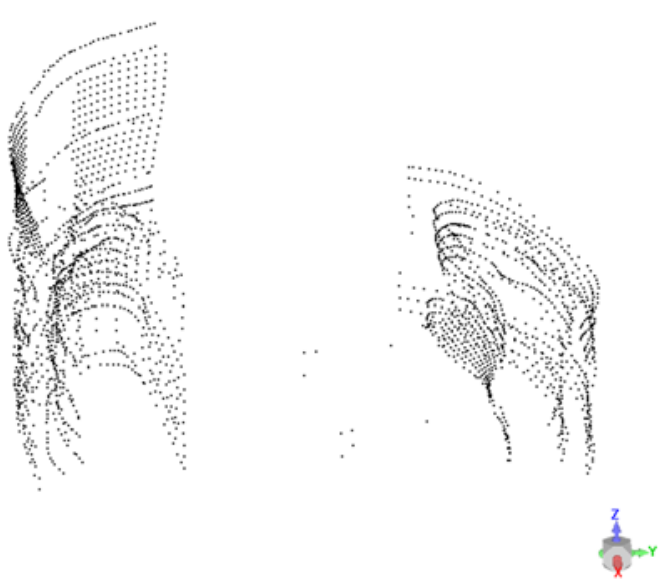

Figure 8: The 3D point cloud created
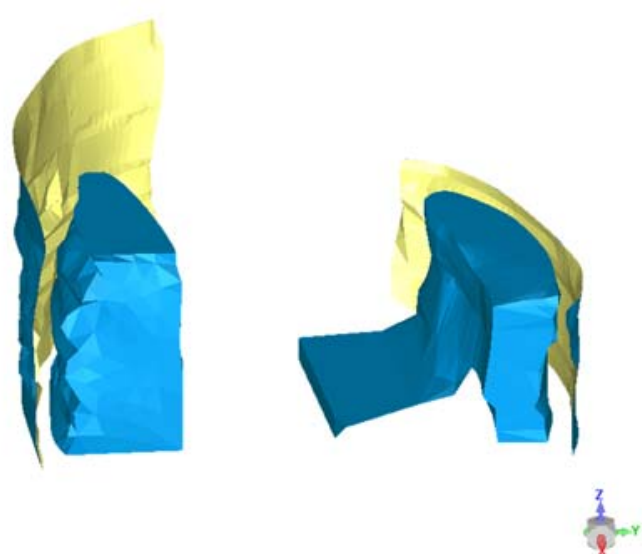

Figure 9: 3D visualization of the prospection findings 
Finally, the 3D surface model created was incorporated into the existing high resolution 3D model of the interior of the Holy Aedicule, where its position in relation to the common reference system and to the various details was established (Figure 10).

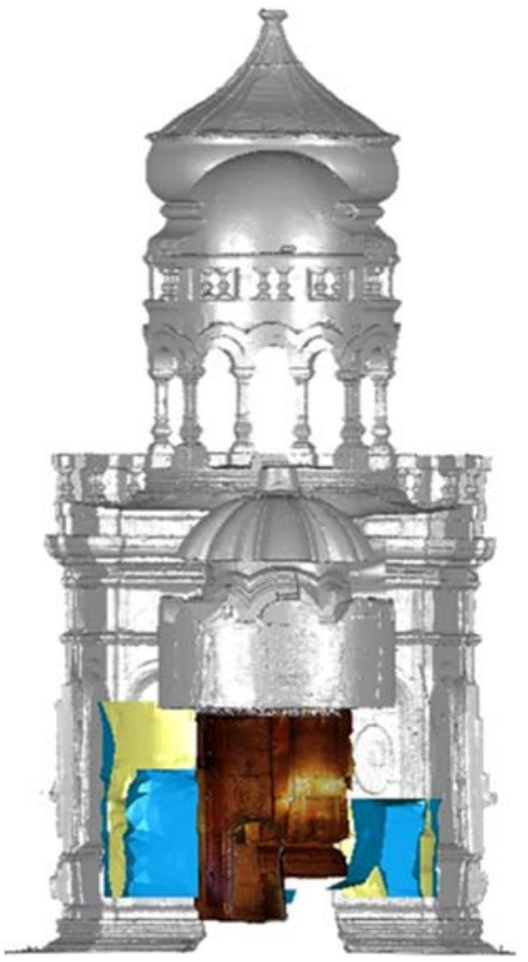

Figure 10:3D visualization of the prospection findings: The scanned 3D model (grey) with the 3D GPR data

\section{CONCLUSIONS}

In this paper a new methodology has been presented, which enables the 3D modelling of a hidden structure detected by nondestructive (NDT) prospection techniques. The development of the procedure was realized under the pressing real working conditions of the restoration site in situ.

The results were recently verified by the ongoing work in Jerusalem, when the excavations have revealed part of the original Holy Rock.

It constitutes a decisive step towards the exploitation and interrelation of GPR data and high resolution 3D models, thus enabling the detailed study of the Holy Aedicule. The results offer valuable additional data to the experts and the process may be expanded to exploit all qualitative NDT measurements performed in a monument. The procedure could be automated in order to incorporate more objectively the various data coming from all the qualitative sources.

The 3D modelling of the rock has greatly contributed to the archaeological, historical and architectural studies of the monument. In addition, it has provided valuable information for the practical implementation of the conservation works, especially for the process of grouting.

\section{ACKNOWLEDGEMENTS}

The project became possible and is executed under the governance of His Beautitude Theophilos III, Patriarch of Jerusalem. The Common Agreement of the Status Quo Christian Communities responsible for the Holy Sepulchre provides the statutory framework for the execution of the project. Contributions from entities and persons all over the world secure the project's funding. Worth noting Mica Ertegun's donation through WMF, Aegean Airlines et al. Additionally, for the 3D models of the Aedicule presented here, the contribution of Profs. Ch. Ioannidis, E. Lamprou, G. Pantazis and S. Soile, S. Tapinaki, L. Kotoula and A.I. Papadaki, members of the Geometric Documentation team is gratefully acknowledged

\section{REFERENCES}

Balodimos, D., Lavvas G., Georgopoulos, A., 2003. Wholly Documenting Holy Monuments CIPA XIX International Symposium, 2003, Antalya. http://cipa.icomos.org/text\%20files/antalya/133.pdf

Biddle, M., 1999. The Tomb of Christ. Sutton Publishing Ltd., ISBN 0-7509-1926-4, 173pp.

Biddle, M., Cooper, M.A.R., Robson, S., 1992. The Tomb of Christ, Jerusalem: a photogrammetric survey, The Photogrammetric Record, 14(79), 25-43.

Binda, L., Lenzi, G., \& Saisi, A., 1998. NDE of masonry structures: use of radar tests for the characterisation of stone masonries. NDT \& E International. 1998; 31(6): 411-419

Binda, L., Saisi, A., \& Tiraboschi, C., 2000. Investigation procedures for the diagnosis of historic masonries. Construction and Building Materials. 2000; 14: 199-233

Corbo, V.C., 1981. Il Santo Sepolchro di Gerusalemme. 3 vols. Publication of the Studium Biblicum Franciscanum 29, Jerusalem.

Georgopoulos, A., Modatsos, M., 2002. Non-metric bird's eye view. International Archives of Photogrammetry and Remote Sensing, 34(5), 359-362, Corfu, Greece.

Labropoulos, K., Moropoulou, A. 2013. Ground penetrating radar investigation of the bell tower of the church of the Holy Sepulchre. Construction and Building Materials. 2013; 47, 689700

Lavvas, G., 2009. The Church of the Holy Sepulchre in Jerusalem, Academy of Athens, 2009, 192 p., ISBN 978-960404-139-8 (in Greek).

Moropoulou A. I., Labropoulos K.C., 2015. "Non-Destructive Testing for Assessing Structural Damage and Interventions Effectiveness for Built Cultural Heritage Protection", in: P.G. Asteris, V. Plevris (Eds.), Handbook of Research on Seismic Assessment and Rehabilitation of Historic Structures, IGIGlobal, Hershey, PA, USA. 2015; 448-499

Moropoulou, A., Korres, E., Georgopoulos, A., Spyrakos, C., 2015. Integrated Diagnostic Research Project and Strategic Planning for Materials, Interventions, Conservation and Rehabilitation of the Holy Edicule of the Holy Sepulchre in the Holy Church of the Resurrection in Jerusalem. Interim report (unpublished).

Moropoulou, A., Labropoulos, K.C., Delegou, E.T., Karoglou, M., \& Bakolas, A., 2013. Non-Destructive Techniques as a tool for the protection of Built Cultural Heritage. Construction and Building Materials. 2013; 48: 1222-1239

Tucci, G., Bonora , V., 2011. Geomatic techniques and 3D modeling for the survey of The church of the Holy Sepulchre in Jerusalem. Proceedings XXIII CIPA Symposium - Prague, Czech Republic - 12/16 September 2011. 